\title{
ПРОТОТИПИ ПЕРЦЕПТИВНИХ ОЗНАК У ВЕКТОРІ ЛІНГВІСТИЧНОЇ ОБ'ЄКТИВАЦІЇ
}

\author{
НАТАЛІЯ ПАРАСІН \\ Київський національний університет імені Тараса Шевченка, Київ - Україна \\ parasin@ukr.net; ORCID: 0000-0001-7027-0266 \\ PROTOTYPY CECH PERCEPCYJNYCH \\ W SFERZE OBIEKTYWIZACJI JEZZYKOWEJ
}

NATALIA PARASIN

Kijowski Uniwersytet Narodowy imienia Tarasa Szewczenki, Kijów — Ukraina

STRESZCZENIE. Uwaga badawcza koncentruje się na metodach wykrywania i badania prototypów. Udowodniono zależność prototypu od kategorii wybranej do analizy. Istnieją trzy główne kategorie, w których cecha percepcyjna jest zobiektywizowana: rzeczywista kategoria znaku percepcyjnego, kategoria obiektów znaku percepcyjnego, kategoria pola semantycznego znaku percepcyjnego. W świetle powyższego rozróżnia się leksykalne, referencyjne i semantyczne prototypy znaku cechy percepcyjnej.

Słowa kluczowe: prototyp, cecha percepcyjna, obiektywizacja językowa, językoznawstwo ukraińskie.

\section{PROTOTYPES OF A PERCEPTIVE SIGNS IN THE VECTOR OF LINGUISTIC OBJECTIVES}

\author{
NATALIA PARASIN \\ Kyiv Taras Shevchenko National University, Kiev — Ukraine
}

\begin{abstract}
The article focuses on the analysis of the methods of detection and research of the prototypes. The dependence of the prototype on the category selected for analysis has been proved. There are three main categories in which the perceptual feature is objectified: the actual category of perceptual sign, the category of perceptual representatives, the category of the semantic field of the perceptual sign. Accordingly, the lexical, reference and semantic prototypes of the trait sign have been distinguished.
\end{abstract}

Key words: prototype, perceptive features, linguistic objectives, Ukrainian linguistics.

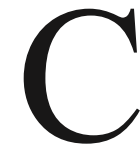

учасний інтерес до перцепції пояснюють тим, що вирішення будь-якого когнітивного завдання загрунтоване в аналізі процесу сприйняття довкілля, оскільки когніція охоплює різні форми осягнення світу, а вонипочинаються 3 перших контактів людини з довкіллям. Установлення тісного зв’язку між перцепцією і ментальністю спричинило перегляд базових положень традиційного мовознавства й наближення його до антропологічної системи координат.

Основні віхи процесу сприйняття експлікує тріада понять “суб'єкт сприйняття - процес сприйняття - об'єкт сприйняття”. Попри складний і розгалужений характер сенсорної дії, перцепцію традиційно пов'язують насамперед з ознаками, фіксованими органами чуття. У структурі акту сприйняття і фіксації знань перцептивна ознака експлікує прототипну категорію 3 притаманними їй структурними, семантичними, функціональними особливостями. Незважаючи на порівняно велику кількість праць, спеціально чи принагідно при- 
свячених вивченню окремих перцептивних модусів, категорія сенсорної ознаки як фактор процесу сприйняття й осягнення специфіки всесвіту цілісно ще не була об’єктом дослідження, що зумовлює мету статті - окреслити вектори лінгвістичного дослідження категорії перцептивної ознаки в координатах прототипного підходу.

У складній і багатоярусній системі сучасної когнітивної термінології “прототип” локалізовано з позицій сьогодення в низці класичних, засадничих термінів, про що свідчить його активна апробація й ратифікація на теренах усесвітньої наукової спільноти (див. огляд), проте в україніці, як і в усій східнослов'янській лінгвістиці, переважає методика виявлення гносеологічних можливостей концептуального підходу, що певною мірою перекрив русло розвитку прототипології. У світлі сказаного зростає роль праць, у яких прототип як когнітивний феномен використано в ролі методичного й дефініційного центру наукових досліджень (І. Голубовська, А. Левицький, О. Левченко, Л. Ніжегородцева-Кириченко, В. Сидоренко, Н. Слухай, В. Старко та інші).

Історія прототипного способу сприйняття людиною довкілля бере витоки зі сформованої в перш. пол. ХХ ст. філософської течії критичного ставлення до класичних принципів категоризації, за постулатами якої категорія формується на основі необхідних і достатніх ознак, а відтак не залежить від суб'єкта категоризації; іiі члени незалежні один від одного й рівноправні; категорія являє собою чітко окреслену структуру з неперехідними межами. Наукові студії сер. XX ст. привели до зміни засадничих критеріїв категоризації. Увагу дослідників різних галузей привернула програмова теза психологів - представників “Нового погляду": осягнути особистість можна шляхом аналізу процесу сприйняття, а теорія сприйняття має розвиватися на визнанні творчої ролі перцепієнта ${ }^{2}$, відтоді гносеологічні принципи механізмів класифікації скеровано на пошуки певної норми, що найбільш повно відповідає основним параметрам аналізованого поняття. Чільне місце серед здобутків цього періоду посідають уявлення про сприйняття цілісного (а не поетапного) образу людиною представників гештальтпсихології, ідеї про когнітивну нерівноправність членів категорії, висновки про наявність відношень сімейної подібності між членами категорії, обгрунтування поняття лінгвістичної змінної тощо, що було змодельовано, верифіковано, значною мірою доповнено і структуровано Е. Вітгенштейном, Е. Рош, Дж. Лакоффом, В. Лабовим та іншими класиками когнітології. Зокрема, американський психолог Е. Рош, яку за правом вважають автором теорії прототипів і категорій базового рівня, зауважила невідповідність між законами класичної класифікації і власними експериментальними дослідженнями, чітко сформулювавши пропедевтичні теоретичні вектори проблеми: якщо категорії визначаються тільки за допомогою ознак, притаманних усім членам категорії, то жоден із цих членів не може бути кращим прикладом категорії, аніж інші ${ }^{3}$. У процесі осмислення численних експериментів Е. Рош дійшла висновку про нерівноправність членів категорії. На ії думку, категоризація відбувається на основі моделювання прототипу як найкращого взірця категорії і подальшого зістав-

${ }^{1}$ R. MacLaury, Prototypes revisited, [in:] „Annual Reviev of anthropology”, 1991, nr. 20, p. $55-74$.

2 А. Асмолов, По ту сторону сознания: методологические проблемы неклассической психологии, Москва 2002, [в:] Электронный ресурс: http://cl.rushkolnik.ru/docs/7840/index-47990. html?page $=32(24.12 .2017)$.

3 E. Rosch, "Focal" color areas and the development of color names, [in:] „Developmental Psychology", 1971, nr. 4, p. 449. 
лення нових об'єктів - можливих членів певної категорії - 3 прототипом. Такий процес дає змогу ідентифікувати об'єкти майже миттєво, натомість зіставлення за списком необхідних і достатніх ознак, яких може бути немало, вимагає певного часу 4 . Основні положення теорії прототипів конкретизовано Г. Кляйбером$\left.^{5}: 1\right)$ категорії притаманна внутрішня структура; 2) рівень презентативності екземпляра відповідає рівню приналежності його до категорії; 3) межі між категоріями розмиті; 4) члени однієї категорії не обов'язково мають однакові властивості, швидше їх поєднує сімейна схожість; 5) віднести певний об'єкт до певної категорії можна на підставі схожості з прототипом; 6) дослідник вивчає матеріал не аналітичним, а синтетичним, або “глобальним", способом. Порівняно довгий час протототипний підхід розвивався в кількох дисциплінах майже незалежно: у когнітивній психології, етнолінгвістиці, теоретичному мовознавстві й у філософії. У кожній з них із часом відбулось ускладнення теоретичних, методологічних і методичних аспектів роботи, що спричинило появу нових наукових дослідницьких завдань, з-посеред яких донині залишаються актуальними проблеми, визначені російським мовознавцем Н. Болдиревим ${ }^{6}$ : 1) які елементи мови виступають у ролі опорних точок (когнітивних точок референції, за Е. Рош) у процесах формування й передачі змісту, тобто в ролі прототипів, і якою є їхня типологія; 2) чим зумовлено вибір певного слова при відтворенні смислу висловлювання; 3) як зіставляються (і чи зіставляються загалом) прототипи категорій немовних об'єктів і прототипи мовних категорій (немовні й мовні прототипи, прототипи ментального й мовного рівнів) та багато інших, що потребують об’єднаних зусиль представників різних наук. Вибором матеріалу дослідження - сенсорної ознаки - зумовлено першочергову потребу аналізу проблем, дотичних до обраної теми дослідження.

У пропонованій студії виокремлено три засадничі моменти теоретичного обгунтування прототипного аналізу сенсорної ознаки: 1) проблема кореляції прототипного аналізу в субкатегоріях різного виду; 2) проблема форми втілення прототипу в категорії сенсорної ознаки; 3) проблема виявлення й методики дослідження прототипів на рівні семантики ознаки.

Прототип як теоретичний гносеологічний конструкт є частиною теорії категоризації і класифікації, відтак виявлення й характеристика прототипів залежить від категорії, обраної для аналізу. У першому й другому визначених пунктах матеріалом дослідження $є$ категорія сенсорної ознаки в іiї лексичному мовному відображенні, у третьому пункті основою студіювання є семантична категорія сенсорної дескрипції.

1. Аналіз сенсорної ознаки став класичним прикладом прототипного аналізу (Е. Рош, Б. Берлін, П. Кей), проте проблема донині залишається в полі зору мовознавців, оскільки висвітлюються нові грані проблематики. Насамперед зазначимо, що в останні роки значного розширення й ускладнення набуло вчення про категорії. Паралельно відбувається розвиток форм, структури та дефініціювання прототипів. Так, ще Дж. Лакофф (услід за Ф. Лаунсбері) локалізував категорію кольору в структурній групі прототипів генеративних, а катего-

\footnotetext{
${ }^{4}$ Ibidem, p. 450.

${ }^{5}$ G. K1eiber, La sémantique du prototype: Catégories et sens lexical, Paris 1990, p. 71.

${ }^{6}$ Н. Н. Болдырев, Прототипы в языковой категории знаний, [в:] „Проблемы представления (репрезентации) в языке: Типы и форматы знаний”, 2007, вып. 2, с. 30.

${ }^{7}$ В. Ф. С тарко, Основні типи категорій в мовно-когнітивних дослідженнях, [в:] „Мовознавчий вісник", 2008, вип. 6, с. 238-243.
} 
рію розміру відніс до градуальних ${ }^{8}$, проте і в одному, і в другому випадках простежуємо прототипні ефекти, проте категорія сенсорної ознаки не отримала логічного структурного завершення. Зрештою, до виявлення сенсорних прототипів спонукає панівна нині доктрина сприйняття світу людиною, за постулатами якої перший етап осмислення людиною довкілля результативує сенсорні образи. Отже, одне з основних питань прототипології в царині сенсорної ознаки постає у вигляді спектру дослідницьких завдань, спрямованих на виявлення / заперечення прототипних основ сенсорних категорій різних перцептивних модусів (візуального, аудіального, тактильного, одоративного, густативного) та, що важливо, окремих субмодусів (напр., колірного та параметричного в межах модусу зору), що демонструють зони структурного незбігу. Це дасть змогу виявити способи організації мовної категорії сенсорної ознаки, їі структуру та способи міжкомпонентного зіставлення.

2. Сьогодні не існує єдиного й задовільного для всіх визначення прототипів, й інколи це ставлять у вину самій Е. Рош, мовляв, іiі різнопланові й не зовсім чіткі висловлювання не дають змоги укласти досліджувані прецеденти в єдине русло. Почасти це справедливо, але, на нашу думку, із теорією прототипів відбувся закономірний процес, характерний для кожного неординарного наукового явища, що відкриває нові обшири досліджень — розмивання дефініційних ознак, розвиток багатозначності й навіть утворення омонімії в термінологічному апараті, що обслуговує вчення (порівняймо аналогійні процеси, що спричинили численні дефініції термінів “концепт”, “скрипт” тощо; різне - аж до протилежного - розуміння фрейму тощо). Відтак логічно повернутися до першовитоків: уже в одній із своїх ранніх робіт Е. Рош підкреслила, що „когнітивна репрезентація колірних категорій уміщує інформацію, що використовується у сприйнятті кольору як фізичного стимулу (щось подібне до конкретного взірця кольору), до того ж репрезентація (образ) більше нагадує “хороші", аніж “погані" елементи колірної категорії” (тут і далі виділення й переклад автор. - Н. П. $)^{9}$. Виділені лексеми конкретизують двояке розуміння Е. Рош прототипу: як умоглядного образу і як конкретного, реального взірця категоpiï. Ідея ментального характеру прототипів послідовно проводилася автором і в дослідженнях інших категорій, проте паралельно розвивалося експериментальне обгрунтування наявності певного конкретного об' єкта, що може репрезентувати категорію загалом і виконувати роль прототипу, оскільки „найбільш економним з когнітивної точки зору їхнім (ментальних репрезентацій - Н. П.) кодом $\epsilon$ конкретний образ типового представника категорії'10. Відтак у лінгвістиці термін “прототип” теж осмислюється як салієнтне явище двопланового характеру. О. Селіванова тлумачить прототип як мисленнєвий корелят найкращого взірця певного класу об' єктів згідно із концепцією родинної схожості Л. Вітгенштейна, або найбільш типовий цілісний представник категорії, вибір якого пов'язаний $з$ досвідом людини, виробленим шляхом їі пізнавальної діяльності й особливостями ііі мислення ${ }^{11}$. 3 огляду на сказане постає питання про результативність форм референтного й ментального способу прототипної експлікації сенсорної ознаки.

8 Дж. Лакофф, Женщуины, огонь и опасные вещуи: Что категории языка говорят нам о мылилении, Москва 1987, с. 44.

${ }^{9}$ E. Rosch, Human Categorization, [in:] „Studies in Cross-Cultural Psychology”, 1977, nr 1, p. 15.

${ }^{10}$ E. Rosch, B. Lloyd, Principles of Categorization, [in:] Eleanor Rosch \& Barbara

B. Lloyd (eds.). Cognition and Categorization, New York 1978, p. 30.

11 О. Селіванов а, Сучасна лінгвістика: термінологічна енциклопедія, Полтава 2006, с. 504. 
Зіставлення номінації сенсорної ознаки з ії вірогідним референтом (зіставлення сигніфікатного та денотатного рівнів) і виявлення архітектоніки самих референтів певної ознаки є визначальним для аналізу категорії ознаки, оскільки закон онтологічного зв'язку між сенсорною ознакою та ії референтном дієвий і нині (гірчичний - присмак, колір). Відтак аналіз референтного (предметного) прототипу зорієнтовано на виявлення конкретного типового компонента категорії, що може іiі презентувати загалом. Донині взірцевими в цьому напрямі роботи вважають експерименти Е. Рош, яка довела існування типових фруктів, птахів, меблів, видів зброї тощо ${ }^{12}$. Мусимо зауважити потребу в українському мовознавстві цілісних напрацювань, так би мовити, класичного характеру, зокрема, в дусі експериментів Е. Рош та інших представників прототипології, оскільки їхня відсутність залишає лакунарною значну галузь досліджень, що дала б змогу виявити специфіку відповідного сегмента етнічної картини світу. Аналіз перцептивної ознаки в указаному напрямі має певну специфіку. Якщо денотатним прототипом категорії об'єктів $є$ об'єкт, денотатним прототипом категорії дії є дія, то виявлення референтного прототипу ознаки корелює 3 визначенням об'єкта-субстантива, пов'язаного з ад'єктивом певним типом зв'язку. Ознака трактується через об'єкт, у якому вона виступає як найбільш репрезентативна, визначальна для сприйняття чи типова. Мовні форми (слова, словосполучення), що експлікують ознаку, не можуть існувати окремо від предметів чи явищ, які вони характеризують і які визначають семантику й функціонування ознакового комплексу. Мовна експлікація властивості є результатом абстрагувальної діяльності свідомості, що приводить до виокремлення й ментального сприйняття властивості, відокремленої від носія.

Отримавши автономне словесне оформлення, властивість не набула об'єктивної самостійності, перебуваючи в полі семантичних, асоціативних, граматичних тощо векторів іменника, що виступає референтом опису. На цю специфіку перцептивної ознаки звернула увагу А. Вежбицька, яка постулює свій підхід до аналізу кольоропозначень як семантичний. Значення слів, - на думку названого мовознавця, - це те, що ми маємо на увазі, коли вимовляємо слово. А оскільки те, що ми маємо на увазі, залежить від контексту, або ситуації, то значення - це тільки постійні, незмінні умови вживання слів ${ }^{13}$. Прототип у розумінні А. Вежбицької - це ментальний образ конкретної реалії довкілля (стосовно кольору це насамперед об'єкти пейзажу) ${ }^{14}$, що спадає на думку під час сприйняття лексеми. Відтак колірні компоненти пов'язані з певними “універсальними елементами людського досвіду", і ці універсальні елементи можна спрощено визначити як “день” і “ніч”, “сонце”, “вогонь”, "рослинність”, “небо” i “земля"15.

Залежно від ситуації аналізу й методики дослідницької діяльності предметні референтні прототипи набирають форми асоціативних, еталонних, семантично-денотатних, історичних, формальних тощо об'єктивацій ${ }^{16}$. Асоціативний референтний прототип установлюють на основі реакцій респондента на певний вербальний або невербальний сенсорний стимул. Найбільш діє-

12 E. Rosch, Cognitive representations of semantic categories, [in:] „Journal of Experimental Psychology", 1975, nr 104, p. 192-233.

13 А. Вежбицкая, Язык. Культура. Познание, Москва 1996, с. 243.

${ }^{14}$ Там же, с. 233.

15 Там же, с. 283.

${ }^{16}$ Н. Парасин, Виды референтного прототипа, [в:] „Филологические науки. Вопросы теории и практики", 2014, № 8 (38), ч. 1, с. 146-149. 
вим методом виявлення реального значення вважають асоціативний експеримент, що дає змогу відтворити структуру асоціативного поля, вивчити індивідуальні стратегії асоціювання тощо. Матеріали для аналізу презентовано в асоціативних словниках, у результатах окремих асоціативних студій тощо. Еталонний референтний прототип експлікує ознаку в ії найбільш яскравому, виразному прояві, здатному впливати на підсвідомі процеси запам'ятовування й референції, його використовують як критерій семантичного визначення при укладанні тлумачних словників, еталон зафіксовано в порівняннях (білий як сніг) тощо. Частотно-референтний прототип виявляється у формі найбільш частотних референтах ознаки в мові й мовленні. Його аналіз залежить від кількості та якості наявних словників частотного вживання, аналітичних робіт, виконаних на основі різного виду текстів (не тільки художніх), зрештою, від частотного аспекту вивчення так званого живого усного мовлення. Отже, референтні прототипи експліковано в найбільш типових, частотних або салієнтних словосполученнях, що відтворюють поєднання ознаки з певними об'єктами. Нові ракурси в дослідженні можуть виникнути при зіставленні різних референтних прототипів і виявленні так званого етнічного референтного прототипу, що, на нашу думку, сприятиме деталізованому змалюванню картини світу представника українського етносу.

3. Третій напрям вивчення прототипів побудовано на усвідомленні того, що прототипна схематизація полісеманта або узагальненої семантики конституентів категорії дасть можливість уникнути помилок, спрямованих на установлення вичерпної множини значень, проте, залишаючи подібні завдання в царині “чистої” семантики, звертаємо увагу на те, що ступінь членства в прототипній категорії градуальний, а розмитість меж передбачає не тільки існування нечіткої множини значень, але і їхній можливий розвиток. Для лексикологів поняття прототипу експлікує теорію, здатну вирішувати проблему лексичного смислу. Власне, перехід від антропологічної семантики (“семантики класу”) до лінгвістичної семантики засвідчили численні праці кінця $\mathrm{XX}$ ст. $^{17}$, присвячені пошукам прототипних властивостей лексичної семантики як окремої категорії.

Структурна організація категорії впливає на їі когнітивне опрацювання за допомогою виявленого Е. Рош механізму дії “точок когнітивної референції” (“cognitive reference points") ${ }^{18}$. Дефініція терміна “точка когнітивної референції” в тлумаченні Е. Рош не подана, окрім того, він використовується в різних ситуаціях, що певною мірою посилює його термінологічну невизначеність. На основі праці Е. Рош виділяємо два аспекти конкретизації терміна: 1) об'єкт, за посередництва якого відбувається засвоєння або заперечення приналежності інших об'єктів до певної категорії; 2) вектори, на основі яких відбувається зіставлення об'єктів та їхнє об'єднання в категорії. Розвиваючи другий підхід, уважаємо доцільним виявити ті основні семантичні напрямки, на основі яких відбувається розвиток текстової семантики індивідуальних перцептивних прототипів.

${ }^{17}$ D. Cruse, Prototype Theory and Lexical Semantics, [in:] „Meaning and Prototypes: Studies in Linguistic Categorization", London and New York 1990, p. 382-402; G. Kleiber, La semantique du prototype: Categories et sens lexical, Paris 1990; W. Labov, The Boundaries of Words and Their Meanings, [in:] „New Ways of Analyzing Variation in English”, Washington 1973, p. 340-373; V. Nyckees, Categories semantiques et historicite des significations [in:] „Historie. Epistemologie. Language", 1997, t. 19, fasc. 1, p. 97-119.

${ }^{18}$ E. Rosch, Cognitive reference points, [in:] „Cognitive Psychology”, 1975, nr. 27, p. 532-547. 
Практичний аналіз матеріалу, зокрема поетичної мови Т. Шевченка ${ }^{19}$, дає підстави виділити загальні для рівня семантичного авторського прототипу вектори когнітивної референції, об' єктивовані такими текстовими смислами, як онтологічний, філософський, вітальний, емоційний, кордоетнічний, сакральнофатумний, аксіологічний тощо. Дієвими на цьому рівні є методи, пов'язані з дослідницькою інтерпретацією текстової семантики.

Отже, теорія прототипів демонструє широкі можливості в царині мовознавчого дослідження перцептивної ознаки. Окреслені в статті проблемні вектори потребують різнобічної практичної апробації та дослідницької верифікаціï.

\section{Список використаної літератури}

Асмолов А., По ту сторону сознания: методологические проблемы неклассической психологии, Москва 2002, [в:] Электронный ресурс: http://cl.rushkolnik.ru/docs/7840/ index-47990.html?page $=32(24.10 .2017)$.

Болдырев Н. Н., Прототипы в языковой категории знаний, [в:] „Проблемы представления (репрезентации) в языке: Типы и форматы знаний”, 2007, вып. 2, с. 29-37.

Вежбицкая А., Язык. Культура. Познание, Москва 1996.

Лакофф Дж., Женщины, огонь и опасные вещи: Что категории языка говорят нам о мылилении, Москва 1987.

Парасин Н., Виды референтного прототипа, [в:] „Филологические науки. Вопросы теории и практики", 2014, № 8 (38), ч. 1, с. 146-149.

Парасін Н., Когнітивні аспекти дослідження семантики кольоропозначень, [в:] „Вісник Київського національного університету імені Тараса Шевченка. Серія «Мова. Література. Фольклористика», 2013, № 1 (24), с. 35-38.

Селіванова О., Сучасна лінгвістика: термінологічна енциклопедія, Полтава 2006.

Старко В. Ф., Основні типи категорій в мовно-когнітивних дослідженнях, [в:] „Мовознавчий вісник", 2008, вип. 6, с. 238-243.

Cruse D., Prototype Theory and Lexical Semantics, [in:] „Meaning and Prototypes: Studies in Linguistic Categorization", London and New York 1990, p. 382-402.

Kleiber G., La semantique du prototype: Categories et sens lexical, Paris 1990.

Labov W., The Boundaries of Words and Their Meanings, [in:] „New Ways of Analyzing Variation in English", Washington 1973, p. 340-373.

MacLaury R., Prototypes revisited, [in:] „Annual Reviev of anthropology”, 1991, nr. 20, p. 55-74.

Nyckees V., Categories semantiques et historicite des significations [in:] „Historie. Epistemologie. Language", 1997, t. 19, fasc. 1, p. 97-119.

Rosch E., "Focal" color areas and the development of color names, [in:] „Developmental Psychology", 1971, nr. 4, p. 449.

Rosch E., Cognitive reference points, [in:] „Cognitive Psychology”, 1975, nr. 27, p. 532-547.

Rosch E., Cognitive representations of semantic categories, [in:] „Journal of Experimental Psychology", 1975, nr 104, p. 192-233.

Rosch E., Human Categorization, [in:] „Studies in Cross-Cultural Psychology”, 1977, nr 1, p. 1-49.

Rosch E., Lloyd B., Principles of Categorization, [in:] Eleanor Rosch \& Barbara B. Lloyd (eds.). Cognition and Categorization, New York 1978.

${ }^{19}$ Н. Парасін, Когнітивні аспекти дослідження семантики кольоропозначень, [в:] „Вісник Київського національного університету імені Тараса Шевченка. Серія «Мова. Література. Фольклористика», 2013, № 1 (24), с. 35-38. 


\section{Spysok vykorystanoi literatury \\ [References]}

Asmolov A., Po tu storonu soznanija: metodologicheskie problemy neklassicheskoj psihologii [Reverse Side of Consciousness: Methodological Problems of Non-Classical Psychology], Moskva 2002, [v:] E’lektronnyj resurs: http://cl.rushkolnik.ru/docs/7840/ index-47990.html?page $=32(24.10 .2017)$.

Boldyrev N. N., Prototipy $v$ jazykovoj kategorii znanij [Prototypes of Linguistic Category of Knowledge], [v:] „Problemy predstavlenija (reprezentacii) v jazyke: Tipy i formaty znanij", 2007, vyp. 2, s. 29-37.

Vezhbickaja A., Jazyk. Kul'tura. Poznanie [Language. Culture. Cognition], Moskva 1996.

Lakoff Dzh., Zhenshhiny, ogon' $i$ opasnye veshhi: Chto kategorii jazyka govorjat nam o myshlenii [Women, Fire and Dangerous Things: What Language Categories Tell us about Thinking], Moskva 1987.

Parasin N., Vidy referentnogo prototipa [Types of Referent Prototype], [v:] „Filologicheskie nauki. Voprosy teorii i praktiki”, 2014, № 8 (38), ch. 1, s. 146-149.

Parasin N., Kohnityvni aspekty doslidzhennia semantyky koloropoznachen [Cognitive Aspects of Semantics Colour Markers Research], [v:] „Visnyk Kyivskoho natsionalnoho universytetu imeni Tarasa Shevchenka. Seriia: Mova. Literatura. Folklorystyka”, 2013, № 1 (24), s. 35-38.

Selivanova O., Suchasna linhvistyka: terminolohichna entsyklopediia [Modern Linguistics: Terminological Encyclopedia], Poltava 2006.

Starko V. F., Osnovni typy katehorii v movno-kohnityvnykh doslidzhenniakh [Main Types of Categories in Linguistic Cognitive Researches], [v:] „Movoznavchyi visnyk”, 2008, vyp. 6, s. 238-243.

Cruse D., Prototype Theory and Lexical Semantics, [in:] „Meaning and Prototypes: Studies in Linguistic Categorization", London and New York 1990, p. 382-402.

Kleiber G., La semantique du prototype: Categories et sens lexical, Paris 1990.

Labov W., The Boundaries of Words and Their Meanings, [in:] „New Ways of Analyzing Variation in English", Washington 1973, p. 340-373.

MacLaury R., Prototypes revisited, [in:] „Annual Reviev of anthropology”, 1991, nr. 20, p. 55-74.

Nyckees V., Categories semantiques et historicite des significations [in:] „Historie. Epistemologie. Language", 1997, t. 19, fasc. 1, p. 97-119.

Rosch E., "Focal” color areas and the development of color names, [in:] „Developmental Psychology", 1971, nr. 4, p. 449.

Rosch E., Cognitive reference points, [in:] „Cognitive Psychology”, 1975, nr. 27, p. 532-547.

Rosch E., Cognitive representations of semantic categories, [in:] „Journal of Experimental Psychology", 1975, nr 104, p. 192-233.

Rosch E., Human Categorization, [in:] „Studies in Cross-Cultural Psychology”, 1977, nr 1, p. 1-49.

Rosch E., Lloyd B., Principles of Categorization, [in:] Eleanor Rosch \& Barbara B. Lloyd (eds.). Cognition and Categorization, New York 1978. 